\title{
Innovation by Experimenting in Public Services
}

\author{
Leväsluoto, Johanna
}

SPRINGER-VERLAG SINGAPORE PTE LTD

2019

Leväsluoto , J , Hyytinen , K \& Toivonen-Noro , M I 2019 , Innovation by Experimenting in Public Services . in M Toivonen \& E Saari (eds), Human-Centered Digitalization and Services . Translational Systems Sciences, vol. 19 , SPRINGER-VERLAG SINGAPORE PTE LTD , Singapore , pp. 199-223 . https://doi.org/10.1007/978-981-13-7725-9_11

http://hdl.handle.net/10138/330610

https://doi.org/10.1007/978-981-13-7725-9_11

unspecified

acceptedVersion

Downloaded from Helda, University of Helsinki institutional repository.

This is an electronic reprint of the original article.

This reprint may differ from the original in pagination and typographic detail.

Please cite the original version. 


\title{
Chapter 11 \\ Innovation by experimenting in public services
}

\author{
Johanna Leväsluoto', Kirsi Hyytinen ${ }^{2}$ and Marja Toivonen ${ }^{3}$
}

\begin{abstract}
Experimental development has been suggested to answer the problems of slowness and ineffectiveness in current innovation activities. It is also applied in the public sector, where it raises specific issues due to traditional bureaucracy and strong professionalism. In our study, carried out via interviews, we examined experimental development and its challenges in a middle-sized Finnish city. The experiment focused on a new integrated model of wellbeing that aimed to promote multiprofessional collaboration and citizen empowerment in child and family services. A common service plan and a digital platform were core elements in the model. However, the purpose of the experiment remained too vague to the practitioners and the experiment was stopped before the dead line. Central challenges were the one-sided focus on top-down management, growing workload, and problems of the digital platform. Despite the 'failure', the experiment offered valuable learnings that can be applied in the future. Clarifying the concept of experimenting and improving the collaboration between local activities and governmental policies are among the most important lessons learned.
\end{abstract}

Keywords: Experimental development, public sector innovation, wellbeing services, social services, digitalization

\section{Introduction}

This chapter discusses experimental development in the public sector. It focuses on a case study, and as a background for it, analyzes literature on the benefits of experiment-based innovations and on the specific innovation challenges in the public context. The concept of 'experiment' refers to so-called 'social experiments', in which a pilot test in a real-life context is set up to obtain empirical evidence of the effects of a policy program or some other novel societal solution. The rationale is to observe whether the program works in action and to create a working model that takes into account the success factors and sources of problems in the program (Orr, 1999).

Experimental approaches have been suggested as a more successful innovation model than the traditional linear model, which is based on a highly formalized process. Slowness, rigidity and insufficient effectiveness of the linear model have encouraged search for alternative ways to carry out innovation activities. The proponents of experimentation have argued that this approach suits particularly well to the conditions of modern society. It merges planning and implementation, and in this way favors flexibility which is necessary in answering the challenges of continuous and rapid

\footnotetext{
${ }^{1}$ Johanna Leväsluoto

VTT Technical Research Centre of Finland

e-mail: johanna.levasluoto@vtt.fi

${ }^{2}$ Kirsi Hyytinen

VTT Technical Research Centre of Finland

e-mail: kirsi.hyytinen@vtt.fi

${ }^{3}$ Marja Toivonen

University of Helsinki

email: marja.toivonen-noro@helsinki.fi
} 
changes, typical of the current development (Eisenhardt and Tabrizi, 1995). Experimentation also provides means for rapid learning. Several innovation theorists have highlighted that practical forms of learning are particularly important in innovation; they include learning-by-doing, learning-byusing and learning-by-interacting (Lundvall, 2001). Further, experimental approaches are compatible with the ideas of open innovation, which is one of the cornerstones of the modern views on innovation (Chesbrough, 2011).

Experimental development has gained foothold in the public sector, too. There are, however, specific issues in this context that generate challenges to the adoption of experimental practices. First, the concept of innovation is a newcomer in the public sector (Windrum, 2008); the changes have usually been understood as 'reforms' or 'policy changes' (Christensen, 2012). Second, the inclusion of bottom-up initiatives is often missing as the top-down perspective has traditionally dominated the activities of public administration (Hartley, 2005). Third, the dissemination of the results of experiments is challenging, because experiments are often launched without an allocation of the responsibility and resources for the spread of the results. General models that would facilitate broader applications are rare (Tummers, 2009).

In our study, we examined the manifestation of these challenges in a case in Finland. In 2014, the Finnish Parliament accepted a law on experiment-based development in cities and municipalities for the years 2015-2016. The aims were to promote experimental culture in Finnish municipalities, on the one hand, and to generate more efficient and effective services, on the other. We have studied the implementation of experimental development in a middle-sized Finnish city, in particular, but also interviewed ministerial representatives about the general goals and nation-wide achievements. The specific experiment that we focused on at the local level concerned the introduction of a new integrated model of wellbeing in social services for children and families. The key elements of the model were multi-professional collaboration, a service plan jointly formulated by the customer and the professional, and a digital platform that would support the dialog between the professionals and the customers. The purpose of the experiment was to promote multi-professional team work and citizen empowerment.

After this introduction, we have structured the chapter as follows. In the second section, we present the theoretical backgrounds of our study: the development from linear innovation models towards more experimental approaches and specific issues characterizing innovation in the public sector. In the third section, we describe the context of our empirical study and the methods of data collection and analysis. The fourth section summarizes the results. We have divided the results to those describing the views of the representatives of the local level (our case city) and to those describing the nation-wide perspective of ministerial representatives. In addition, we report lessons learned from the experiment. The fifth and last section includes the concluding discussion.

\section{Theoretical background}

\subsection{From linear to experimental innovation models}

Models based on intra-organizational research and development (R\&D) have dominated the discussion about the innovation process. The ideal has been a sequence of stages: idea generation, screening, evaluation, detailed development, testing and launch. The concept and practical realization of these stage models have been crystallized by the representatives of the 'schools' of NPD (New Product Development) and NSD (New Service Development) (e.g. Cooper and de Brentani, 1991).

The focus of the stage models has been the systematization of development processes, resulting in the increase of visibility of innovation efforts (Toivonen, 2010). The visibility has facilitated the creation of innovation indicators based on the resources allocated. Indicators are used at both the organizational and the policy level. In the latter context, a benefit has been the possibility to adopt

[Type here] 
tools for innovation support and to measure its amount. On the other hand, stage models are timetaking - a problem that was identified soon after their introduction. This problem was answered by a modification that is today generally applied: a parallel conduct of stages (Alam and Perry, 2002).

However, there is an additional problem: in practice, the stage from which the innovation process begins varies and the end of one innovation process is often the beginning of the next. Several researchers have suggested that models of a spiral or circular type correspond better to the complex and recursive nature of innovation than a linear logic (Buijs, 2003). In order to make the stage model to answer better the reality, there has emerged a suggestion that the front-end of innovation should be separated from the later stages. It has been argued that experimental activity, which includes side steps and iterations, particularly characterizes the beginning of an innovation process. Through the separation of the front end, a synthesis has been pursued between creative problem-solving and rational planning (Koen et al., 2001).

Even this solution does not answer the basic challenge: the nature of innovation as a phenomenon whose result is not known beforehand. Engvall et al. (2001) point out that stage models have concentrated on the systematization of the form of the innovation process, but say very little about the content. However, it is just the content which is the main problem: the idea included is still immature and difficult to express in words. Constructing a plan for something which is not wellknown and involves abundantly tacit knowledge is not a reasonable approach. More effective is a strategy which enables the creation of shared experience of the object to be developed. This means that planning and implementation should be merged to some extent.

Also other researchers have questioned the idea that planning always occurs first and is followed by implementation. Moorman and Miner (1998) argue that 'organizational improvisation' is general in practice but often hidden behind a formal description of innovation processes. They identify three circumstances in which this approach is particularly important. First, unexpected stimuli may create the need for action without providing time for planning. Second, this approach might be prompted when planning cannot provide all the details needed in implementation. Third, a situation where much real-time information is available evokes immediate responses. Similarly, Eisenhardt and Tabrizi (1995) suggest experimental innovation with reliance on real-time experience: rapidly building intuition and flexibility are essential on the uncertain path of innovation.

The development of user-based innovation has progressed hand in hand with the non-linear thinking about innovation (Sundbo and Toivonen, 2011). Traditionally, users have been considered important as the source of needs-based information, and still today many organizations interpret user orientation as the gathering and storing of user information. This approach has, however, been criticized as 'superficial' and the elaboration of user information into deeper user understanding has been required. This means that information should be structured, interpreted and shared to make it applicable and to link it to the organizational strategy (Nordlund, 2009). The actual involvement of users is also an emerging trend. In addition to the emphasis on user interaction in the front end, the role of users has been highlighted in the transition from development to implementation (Hasu, 2001).

The possibility of interactive learning highlights the users' role in innovation. The creation of shared experience of the object to be developed requires that both the users and the providers are understood to be innovators. Von Hippel's work (e.g. 1978 and 1986) during three decades has paved the way for this view. According to him, users offer more than an idea for a new product or service. They may provide an innovating organization with the identification of a problem or need, outcomerelated specifications, or even a complete design of a product or service. In newer research, the continuation of the innovation process after the launch has been pointed out. Because novelties have different meanings for different user groups, they are often reinvented: actively interpreted and appropriated by users. Sundbo (2008) calls this phenomenon 'after-innovation'. He states that an innovation is not completed when it is launched, because customers cannot say beforehand what they want. They suggest ideas for improvements when they use the novelty in practice.

[Type here] 
Along with the interest in user-based innovation, a question has been raised about the ways in which user experience could be made continuously flowing into the provider organization. The approach of employee-driven innovation highlights that front-line service workers have understanding on user needs based on the daily interaction. They can transmit real-life information and combine this information with their own ideas. However, the implementation of these ideas requires that the bottom-up processes are recognized and organized by the management. Managers should support employees by allocating resources, and they may also invite employees to participate in top-down innovation processes (Kesting and Ulhøi, 2010).

One interesting employee-driven phenomenon is 'bricolage' (Fuglsang, 2010). Theorization on employees as bricoleurs analyzes their role - not only in the transmitting of ideas - but also in their implementation. Bricolage includes a process of co-shaping an emerging path: various actors offer inputs and gradually build competences via learning by doing and interacting. The boundaries blur between design and implementation, and between rule making and rule following. The bricolage view suggests that in a situation characterized by resource constraints, employees may find innovative solutions based on 'whatever is at hand'. This notion is particularly important in public services which are often developed in the conditions of scarce - even diminishing - resources.

The approach of effectuation (Sarasvathy and Kotha, 2001; Sarasvathy, 2008) is near to the ideas of bricolage. Effectuation has its background in theories that highlight the significance of human resources, relationships, networks and institutions. It suggests the replacement of predictive logic with a means-oriented approach to tackle the uncertain environment and to co-construct novel solutions with stakeholders. The means-oriented approach begins from available resources that are expanded in the courses of action and enable a stepwise clarification of goals. This approach clearly differs from a linear process, which starts from the identification of an initial opportunity, sets a goal, and aims to achieve it in a preselected context (Read et al., 2009).

Adaptive trial and error characterize effectuation and are necessitated by the uncertainties of the current operational environment. In such a situation, predictive information does not support decision making in the best possible way; more reasonable is relying on strategies that enable direct control, co-creation, and transformation of conditions towards positive outcomes. Quickly realized small successes and small failures help avoid the risk that some action would put the entire effort in jeopardy (Sarasvathy and Kotha, 2001). However, this alternative approach must include enough structure to support the utilization of resources and to foster collaborative creativity. It can be achieved via framing the problem comprehensively: using a framework or schema within which specific decisions and their linkages to other decisions can be contextualized. The ability to group problems into fundamental categories and relate them to other problems results in knowledge architectures that link multiple decisions in the task domain over time with feedback and interpretation (Read et al., 2009).

\subsection{Innovation in the public sector}

Public services face today the combined challenge of increasingly wicked problems and scanty financial resources. There is an on-going change in the intervention strategies of public management which reconstructs its responses to economic and social crises, weakened social links and the challenges of welfare state (Harrisson et al., 2010). In addition to incremental improvements that continuously emerge in public organizations, also systemic changes characterize the public sector. However, as mentioned in the introduction, the concept of innovation has only recently been introduced to the conceptual apparatus of public management (Windrum, 2008).

Researchers have also identified a larger, paradigmatic change in the way in which the nature of the public sector and public services has been understood. This change has taken place during the last thirty-forty years and includes the transfer from the traditional public administration to New Public Management (NPM) and further to the emerging Network Governance (NG) (Langergaard, 2011).

[Type here] 
The traditional administrative paradigm held a top-down view of the public sector, which was seen to be based on a bureaucratic and rule-based order. Services were authoritative pursuing equity but not providing users with a possibility to influence (Torfing and Triantafillou, 2013). Changes were initiated top-down via legislation (Hartley, 2005). The traditional paradigm held its dominance until the 1980s when the NPM paradigm was introduced. It brought market mechanisms to the public context: business-type management, lean processes, performance focus, and contracting-out. One of the most important ideas was handling the citizens as customers who have the right to require high service quality and free choice (Rhodes, 1996). NPM also meant that innovation was explicitly articulated as a goal (Langergaard, 2011).

The benefits of NPM are indisputable compared to the earlier bureaucratic view. On the other hand, also its limits have become apparent along with the development towards increasingly complex issues, multiple actors and need for open dialogue (Sørensen, 2002). Consequently, while NPM still has a strong position in the public sector, there is a new paradigm emerging: the so-called Network Governance (NG). It highlights relationships and partnerships, and co-production as the service model (Newman and Clarke, 2009). Efficient intra-organizational processes are no more enough but the crucial issue is the empowerment of citizens. The emphasis on governance over government favors horizontally organized and relatively fragmented systems in which order is achieved through the regulation of self-regulating networks.

Currently, the NG paradigm evolves in parallel with market imitation and the still surviving elements of bureaucracy (Newman and Clarke, 2009). The co-existence of these fundamentally different views is not without contradictions. A central problem is the reconciliation of the top-down thinking, which is a typical element in traditional administration, and the bottom-up views, which belong to the principles of NPM and NG. Contradictions between the top-down and bottom-up approaches are visible at both the organizational level and the policy level.

Strong professional power is a characteristic of public services (Currie et al., 2012). Traditionally, this power was built on 'occupational professionalism', i.e. on a specific discipline and expertise (medical, educational etc.). It emphasized autonomy and self-regulation of work by professional groups, whose expertise places them in a unique position to act best in the users' interests. Both NPM and NG have aimed to change the nature of professionalism towards organizational professionalism (Evetts, 2003). It is a managerialist version of professionalism and serves the interests of the organization rather than professional groups (Hood, 1991). Professionals are expected to be entrepreneurial, creative, and efficient lifelong learners and team workers, who should share and transform their knowledge and cooperate with other professions (Dent and Whitehead, 2002).

In contemporary studies, there is a strand which posits the existence of a hybrid of organizational and occupational professionalism (Skelcher and Smith, 2015). This hybrid perspective provides a good starting point for the consideration of the issue how to promote innovativeness among professionals. The approach of employee-driven innovation (Høyrup, 2012; Kesting and Ulhoi, 2010) has highlighted that actions supporting the wellbeing of employees are relevant in terms of creating a better atmosphere for the adoption of new practices. Flexible service production models that are responsive to the changing needs of the users require a focus on supportive leadership, boosting employees' intrinsic motivation, creativity and well-being. They call for managers to better recognize bricolage: mundane problem-solving activities (Fuglsang and Sørensen, 2011). The needs of users are embedded in the approach of employee-driven innovation but need attention in order to make the interaction with users successful.

According to the idea of network governance, citizens are active partners in planning, creating and shaping the delivery of public services (Moore and Hartley, 2008). 'Citizen empowerment' has been the key concept to understand the citizen participation. WHO (1997) defines empowerment as a process through which citizens get greater control over the decisions and actions affecting their health and wellbeing. This approach views people as subjects and actors who have sufficient skills and self-efficacy to take the responsibility of their conditions in their own hands (Mäkinen, 2006).

[Type here] 
With the rise of information technology and digital applications, citizens have gained new abilities and ways to participate and express themselves in a networked society. In health care, for instance, citizen empowerment through digital platforms has been active area of research and development (R\&D) (Honka et al., 2011). Several studies show that the empowerment of citizens can be accelerated with digital devices and applications (Samoocha et al., 2010; Webb et al., 2010). Digital empowerment has helped to put citizens on the drivers' seat to manage their own wellbeing and lifestyles (Papastergiou et al., 2009).

However, researchers have noted that the potential of service co-production with users and citizens has not been fully understood in the context of public services (Bovaird, 2007). An additional challenge is that professionals often have difficulties to identify the policy programs they are expected to implement (Tummers et al., 2009), which leads to the non-spread of innovations (Ferlie et al., 2005). Understanding the collaborative processes of public service creation and delivery through digital platforms is also insufficient (Bovaird, 2007). To improve the situation, the service culture should be renewed so that it enables both the actual partnership with citizens and the utilization of a variety of communication and interaction channels between citizen and professionals.

\section{Empirical context and methodology}

\subsection{Context of the study}

As mentioned in the introduction, our case context is the experiment-based development in Finnish cities and municipalities in 2015-2016. A specific law accepted by the parliament formed the framework for this development. More than thirty cities and municipalities participated in the project. Six topics were selected for experimentation: educational services, housing services, youth employment, collaboration of public authorities in social security, auditing of municipal operations, and an integrated model for wellbeing (Tempo Economics, 2017). Our study concerned the lastmentioned topic and its implementation in a middle-sized Finnish city. We chose this experiment for our study because it represented a particularly ambitious effort to promote simultaneously employeedriven and user-based practices in innovation. The experiment also highlighted the use of digital tools in the empowerment of citizens in a new sector: social services. (Our study was part of a bigger project that focused on the development of public services in the digital era: 'The revolution of service economy - Human being at the core of digitalization'.)

The city focused its experiment on child and family services. The 'integrated model of wellbeing' included a life-cycle based total offering whose objective was to reinforce the citizens' ability to take responsibility of their own wellbeing and to support this development via multi-professional collaboration. The total offering consisted of social care (child protection and family counselling) and preventive and therapeutic services in the neighboring sectors: daycare, primary schools and health care. The novelties experimented were a service plan to which both the customer and the professionals commit themselves a digital platform as a mutual information and communication channel between citizens and different professionals. Empowering citizens to participate in the planning of services was also an aim.

The integrated services were especially targeted to citizens who have multiple needs for social care and who therefore are in contact with different professionals from different sectors. The focus was on preventive services in order to diminish problems whose afterward relieving requires considerable resources. Four key processes were identified: 1) early discussion about the concerns of citizens, 2) high quality multi-professional collaboration, 3) long-term support to the parenthood, and 4) the development of social skills of both parents and children. These processes were concretized into life-cycle based and integrated service products. A common service plan aimed at collecting together the various plans that were made for the customer, each of them answering a specific need.

[Type here] 
These kinds of service plans have earlier been used in healthcare, for example (Määttä et al., 2014), and they are actively discussed in other sectors, too. The digital platform aimed to facilitate the distribution of information: the professionals and the customer had access to one and the same information. They could also update and complement the service plan that was made in the electronic form and located on the platform.

\subsection{Data collection and analysis}

We applied semi-structured interviews as our main source of data: the topics were decided beforehand but within them, the respondents were given a great deal of freedom (Bryman and Bell, 2011). The interviews were carried out in two rounds. In the first stage, we interviewed the managers and professionals who had participated in the experiment. In the second stage, we interviewed state representatives who had been developing the framework for the nation-wide project. The first-round interviews were carried out between October 2015 and February 2016 and the second-round interviews between November 2016 and February 2017.

In the search for the interviewees, we used snowball sampling. We started the first round by interviewing the local manager of child and family services. Based on her suggestion, we thereafter invited other local interviewees: managers and professionals. The interviews of the managers were conducted individually, and the professionals were interviewed in three groups. The first group consisted of professionals from child protection and family counselling, and prenatal and child health. In the second group, the professionals represented specialist day care, pre-primary education, and therapeutic services (speech and activity therapies). While these two groups were specifically compiled for our interviews, the third group collaborated on a permanent basis: the professionals in this group were responsible for the evaluation of customer needs. They represented family counselling, health services in primary education, day care, and team leaders of child and family services.

The results of the first-round interviews revealed the challenging nature of the experiment; it was actually closed down before the end of the nation-wide project. This made us interested in studying the reactions of the upper city management and the views of the governmental representatives who had been developing the framework for the municipal experiments and the respective law. We applied again snowball sampling. We started the second round by interviewing the head of education and welfare services in the city, and based on her suggestions, requested interviews from two additional local managers who could provide strategic and customer-centric perspectives. She also gave us recommendations for interviewees at the state level: ministerial advisers who had been developing the experiment-based pilots in health and social care. Finally, we interviewed leading experts from the Office of Data Protection Ombudsman. These interviews were included because the sensitivity of the information in social services had been continuously raised as an issue in the interviews; the Ombudsman had also been involved in the preparation of the law for municipal experiments. The summary of the interviewees is presented in Table 1.

Table 1. Summary of the interviews

\begin{tabular}{|l|c|c|}
\hline \multicolumn{1}{|c|}{ Interview rounds } & $\begin{array}{c}\text { Number of } \\
\text { interviewees }\end{array}$ & Time \\
\hline Round 1 & 5 & October \\
\hline Local managers (total) & 5 & \multicolumn{3}{c|}{} \\
\hline
\end{tabular}

[Type here] 


\begin{tabular}{|c|c|c|}
\hline $\begin{array}{ll}\text { - } & \text { Manager of child and family services } \\
\text { - } & \text { Manager of educational services } \\
\text { - } & \text { Manager responsible for the development of the digital platform } \\
\text { - } & \text { Manager responsible for the procurement of child and family services }\end{array}$ & $\begin{array}{l}1 \\
2 \\
1 \\
1\end{array}$ & \multirow[t]{3}{*}{$\begin{array}{l}2015- \\
\text { February } \\
2016\end{array}$} \\
\hline Local professionals (total) & 18 & \\
\hline $\begin{array}{cl}\text { Group 1: } \\
\quad \text { - } \\
\text { - } & \text { Prenild protection and family counselling } \\
\text { Group2: } & \\
\text { - } & \text { Specialist day care } \\
\text { - } & \text { Pre-primary education } \\
\text { - } & \text { Therapeutic services (speech and activity therapies) } \\
\text { Group3: } & \\
\text { - } & \text { Family counselling } \\
\text { - } & \text { Health services in primary education } \\
\text { - } & \text { Day care } \\
\text { - } & \text { Team leaders of child and family services } \\
\end{array}$ & $\begin{array}{l}3 \\
1 \\
3 \\
3 \\
1 \\
1 \\
1\end{array}$ & \\
\hline \multicolumn{3}{|l|}{ Round 2} \\
\hline Local managers (total) & 3 & \multirow{4}{*}{$\begin{array}{l}\text { November } \\
2016 \text { - } \\
\text { February } \\
2017\end{array}$} \\
\hline $\begin{array}{ll}\text { - } & \text { Head of education and welfare services } \\
\text { - } & \text { Strategy manager } \\
\text { - } & \text { Manager responsible for customer processes } \\
\end{array}$ & $\begin{array}{l}1 \\
1 \\
1\end{array}$ & \\
\hline State representatives (total) & 4 & \\
\hline $\begin{array}{ll}\text { - } & \text { Ministerial adviser from the Ministry of Social Affairs and Health } \\
\text { - } & \text { Data Protection Ombudsman } \\
\text { - } & \text { Lawyer from the Office of data Protection Ombudsman }\end{array}$ & $\begin{array}{l}2 \\
1 \\
1\end{array}$ & \\
\hline
\end{tabular}

The main topics of the first-round interviews were:

1) the background of the multi-professional collaboration and its current stage in the child and family services,

2) the role of customers in the multi-professional service interaction,

3) the main elements of the new integrated model of wellbeing,

4) the aims of the new model, concerning particularly the digital service plan, and

5) the managerial challenges linked to the new service practice and to the change pursued.

In the second-round interviews, we focused especially on following topics:

1) the aim of the nation-wide experiment as regards the topic of the integrated model for wellbeing,

2) implementation of the experiment; experiences of implementation,

3 ) impacts of the experiment on local and nation-wide systems,

4) scaling up - the outcomes of the experiment, and

5) continuation based on the results.

All interviews were recorded and transcribed. The analysis and interpretation of the data was conducted in a dialog between theory and empirical findings. The empirical observations were analyzed in the light of the theoretical bases of the study: the experimental approach in innovation and specific issues of the public sector. We did not use any computer-assisted coding tool, but several rounds of analysis were carried out to derive meanings from data and to reduce the amount of data (Huberman and Miles, 1994). While reading the interviews, we uncovered the most common and typical themes, and classified and structured them. In this way, we aimed at creating a holistic, systematic and thorough understanding of the research topic. The quotations in the results sections illustrate the level at which extracts were picked from the material. During the first round, the analysis 
results were presented to the city representatives who participated in the study; a workshop was organized to validate the results and to acquire supplementary information.

\section{Research results}

This section presents the results of our empirical study based on the interviews. It explains first briefly how the experiment - an integrated model of wellbeing in child and family services - was implemented in our case city. Thereafter, the results are presented in two main parts: experiences at the local level and experiences at the state level. (The local interviews from the second round have been combined with those of the first round. An exception is some views of the local head of education and welfare services who also commented issues of governmental policy). In the reporting of the results, the different respondents belonging to the same profession or position have been distinguished from each other by marking them A, B, C etc.

The views of the local actors revealed two main challenges in the experiment: motivational problems among the professionals due to top-down management, and growing workload and problems of the digital platform. In the views of the governmental developers, we identified two main topics: the concept and management of experimental development and the issue of data security and confidentiality. These challenges and topics have been analyzed in different sub-chapters respectively. In addition, there were quite lively discussions on the further development of the experimented model - we report them as lessons learned from the 'failed' experiment.

\subsection{A short summary of the conduct of the experiment}

Our case city was one of the first participants in the national project on experimental development. As many other Finnish cities, also this city had applied the idea of integrated services in healthcare and the results had been promising. Now the managers of social services were eager to test this idea in the services of their sector. A project team was established, and the manager of child and family services was selected as the leader of project. However, she changed her job to another organization after the first project year, and because the project also otherwise was going to its end, a new project manager was not selected.

As the target sector of the development consisted of multiple different units, disseminating information about the goals of the project would have been a key task to make the participants committed. This task was not carried out properly and early enough. The project group asked superiors to tell professionals that there will be a common service plan on a digital platform and this information was also disseminated via direct emails to professionals. The application of the plan was, however, voluntary - demands on its use were not presented, and the cases in which it would be particularly suitable were not specified in detail. Because only a few professionals had participated in the development work, a broader understanding about the purpose of the project did not develop.

A digital platform was considered essential right from the beginning of the project. In social services, the customers usually meet several professionals, but the professionals have not traditionally exchanged information about the customer needs. The only one who can combine information is the customer him-/herself, but he/she cannot evaluate the relevance of various pieces of information without professional help. Thus, the project group started to develop a common digital platform for those parts of customer data that were not too confidential for professional exchange. The design of the platform was purchased from an IT company and was tailor-made for the present purpose. However, the resources reserved for the development were minor, and the platform included many shortcomings. The work was delayed, and the deadlines were postponed many times. The users were 
given the possibility of comments at quite a late stage. When the platform was nearly finished, three implementation sessions were arranged to professionals on the use of the platform.

In addition to the information exchange between professionals, the digital platform was aimed at being a tool for customers and for the interaction between customers and professionals. The idea was that the customer's multi-professional service plan is saved on the platform and thereafter both professionals and customers can update it digitally. To make this idea work, the recruitment of suitable customers was a central task, but turned out to be too difficult. Marketing the service by the professionals was passive due to the above-described unclarity of the novel practice. The end result was that only a couple of customer families willing to use the platform were found. This and other problems led to closing the experiment during the second year. Even the families that preliminarily promised to use the platform did not actually use it.

\subsection{Challenges in the implementation of the experiment at the local level}

\subsubsection{Top-down management and growing workload}

The interview results revealed that the professionals participating in the experiment had positive experiences about working with other professionals and they welcomed new possibilities of multiprofessional practices. They wanted to break down organizational silos and lower barriers between professionals and service users. The interviewees considered that an important positive effect of the new model and the related digital platform was the possibility to see information produced by the professionals of other sectors in common customer cases. Also the managers thought that the new model would improve customer-centricity and the digital tool would make the work of professionals easier because it facilitates the access to information. The citation below presents this view:

'Multi-professional work is an established way of working in the city. A common service plan is a good tool to make this multi-professional work easier.' (Manager responsible for the procurement of child and family services)

However, the way in which the renewal was introduced caused problems. From the beginning, the experiment was led top-down. The idea of the service plan was not co-created; only a few professionals participated in its development. This weak involvement affected negatively on their commitment. Even when organized, many professionals had skipped the participation in the development sessions - tight timetables and the professional priority of the customer work were used as excuses. These problems are illustrated in the following citations:

\footnotetext{
'We got an invitation yesterday to meet next week's Tuesday. We arrange customer appointments two weeks ahead and it is very difficult to fix new times for the customers. You would need to call customers and rearrange the meetings, which might have been cancelled and rearranged many times before. Sometimes I feel that these projects force me to abandon my primary work'. (Representative A of prenatal and child health)
}

'I have a very distant relation to this project and I do not know anything about it. I was not able to participate in the first implementation session in which the model and platform were presented. I have had a lot of work and [I have worked] also overtime hours so I have not had the time to ask my superior about this. I only received the invitation to this meeting [the study workshop] - otherwise, the project is a total mystery to me.' (Representative $\mathrm{B}$ of prenatal and child health)

The professionals were also afraid that the experiment would generate new tasks and responsibilities that would challenge their ordinary work. The interviewees complained about 'a never-ending flow of new tasks' which decreases the face to face -time with customers. In the long run, the increase of the workflow may cause well-being problems.

'The main problem is that there are always more and more responsibilities even though your workload is already full. New tasks are added on the former responsibilities. Nothing is taken away. A key question is how long you

[Type here] 
can increase the workload of professionals. Do we think that they can cope with all these new tasks?' (Representative A of specialist daycare)

The experimental nature of the new model generated concerns, too. The interviewees thought that the new model may just be a pilot and will not become a part of their daily practices. Thus, they had difficulties in motivating themselves to participate actively in the development. Notably, this was not the only development project as the following quotation shows. The interviewees felt it problematic to identify which projects are genuinely impactful in practice and therefore worthy to participate.

\footnotetext{
'There are many experiments starting; in the end, they do not affect any practices. Often these initiatives even stop before they have properly started... Initiatives come and go, come and go. And when you have lot of work, you can continue without realizing the effects of these experiments. It is very difficult to know in which experiments you should take part. Quite often when I have tried to participate and wanted to find out what the idea is in an initiative, the experiment has already disappeared.' (Representative A of pre-primary education)
}

Not only professionals but also managers presented critics against the poor implementation of the project. The manager responsible for customer processes noted that - in addition to the top-down nature of the process - a problem was that no one genuinely took a responsibility of the actual development work. Various managers and professionals were involved in it, but the work was not coordinated and resourced properly. That caused concurrent and divergent processes, in which the professionals did not share the same understanding and targets of the development.

'To really promote project targets, someone should concentrate on this work. We need someone to coordinate and take the overall responsibility ... Otherwise you cannot see required results. In the current project, the idea came from the city management but it was not delegated properly. There were five different managers who were involved in the development. However, it is not enough that five managers bustle around the same topic, if no one takes a real responsibility. If no one has resources or possibility to concentrate on the development, the quality of the work is not good.' (Manager responsible for customer processes)

The problems described above led to a situation that the recruitment of service users was passive. The interviewed professionals told that they felt unsure and did not have all the necessary information to start recruiting customers, as illustrated in the following citation.

'We did not have enough information to fully understand the concept. And because I did not understand it myself, it was not possible to market it to customers as a positive and good tool.' (Representative A of therapeutic services)

\subsubsection{Problems of the digital platform}

The experiment was strongly technology-oriented: the digital platform played a central role in the basic idea of the model. On the other hand, the digital tool came 'out of the blue' to the practitioners - its preparation was in the hands of the management. This situation resulted in misunderstandings: the professionals did not know how the digital tool should be used in practice and what it meant for their daily work. The interviewees pointed out that the introduction of new digital platforms is timeconsuming and requires learning and patience both from the service providers and from the users.

An additional problem emerged from the customized nature of the platform; it was not connected to the other IT platforms used by the professionals. Technically, it was very basic and traditional and did not support the idea of open data. The technical immaturity and problems related to it slowed down the implementation of the common service plan. The interviewees highlighted that the digital tools should work without problems right from the start to ensure the commitment of practitioners. They also called for more 'realism' in the introduction of digital tools: not all workplaces (e.g. daycare homes) have digital equipment, and it is not self-evident either that all users (e.g. immigrants) have computers. There may also be mistrust towards new technology and fears about lost information. The following citations describe these views:

[Type here] 
'In a way, we thought that we could take certain parts from the new digitalized world and link them to the traditional way of providing services which is managed by professionals [and not engage users]. It was a mistake - we created a closed platform; it did not embrace the idea of open data.' (Head of education and welfare services)

'I have seen the platform, but I have to use my private bank codes to get in, because I do not have the necessary equipment in my workplace. However, I have not made any comments on the platform as I do not even know whether I have enough skills to use it.' (Representative A of prenatal and child health)

The success of the experiment would have required changes in the ways of working of professionals. In a digitalized world, citizen participation plays an essential role in the implementation of services and requires new professional competences and new ways of interaction. As they had not been properly considered in this experiment, citizen participation was low. There were also other problems that weakened participation. The customer group, which was selected to the experiment, was very demanding: the customers had multiple needs for social care and their life situations were often very difficult. Their needs were sensitive, which is why they required face to face contact, not digitalized services in the first place. According to the head of education and welfare services, a more successful strategy would have been to concentrate on children and adolescents with moderate problems. In this group, a digitalized platform with a common service plan might have genuinely worked.

'The experiment might have required that the professionals understand their new tasks: they should have been capable to help customers in the use of new digital services. Another issue is that we should have tested the common service plan first with customers who do not have serious problems and multiple needs for care.' (Head of education and welfare services)

\subsection{Challenges from the nation-wide perspective}

\subsubsection{The concept and management of experimental development}

The interviews of governmental representatives revealed more general viewpoints on the challenges of experimentation. According to the interviewed ministry advisors, one of the key problems is that practitioners do not understand the concept 'experimental development'. They are not familiar with this type of development and have not a clear understanding of what the implementation of an experiment requires from their organization. The fundamental insight about the close relationship between experimenting and learning is often missed, and therefore trial and error are not allowed. If the definition and structure of the experiment are not clear, too much time and resources are used for clarifying the terms and 'wondering the implementation'.

According to the ministerial interviewees, the conceptual vagueness is manifested as a lack of leadership and management, and as an unplanned project - experimentation is seen to realize itself automatically. To improve the situation, an experiment should be understood as a process of continuous improvement, which requires careful planning as an integral part and the capacity to learn from mistakes. The interviewees thought that in the present case, the experimentation process was not designed properly and learning from the results was neglected. The following quotations illustrate the opinions related to the fundamental characteristics of experimental development:

'The characteristics of [experimental] development include the possibility to fail. If something does not work then we can try something else. However, this [learning] requires capacity to cope with the errors, document them and make new plans.' (Ministerial Adviser A, Ministry of Health and Social Care)

'To carry out an experiment is challenging; too much time goes to clarifying the conceptual characteristics of the experiment. What happens after the experiment ends should have been thoroughly thought also...' (Ministerial Adviser B, Ministry of Health and Social Care) 
As seen in the last quote, the implementation of results and the creation of new services were raised as another challenge by the governmental interviewees. The projects typically lack dissemination plans, even though the next stages after the experiment should be a target right from the beginning. Some experiments have overcome this challenge and been capable of creating new services, but usually the changes have taken place in the experimenting organization only. Thus, the innovations created are not diffused at a wider scale, and significant impacts in service systems are missing. The interviewees admitted that this is partially caused by the lack of learning practices at the policy level. Common structures do not exist because of the administrative silos and poor collaboration between the ministries. 'Reinventing the wheel' is a trend that replaces learning from the experience of others. Consequently, experiments are detached from each other and good practices do not spread.

'Traditionally. the most difficult phase has been the step of implementing the project results and changing the activities.' (Ministerial Adviser A, Ministry of Health and Social Care)

'A tool for assessing the customer's situation has been developed, but the question is to which activities it should
be integrated or connected at the policy level. The lack of collaboration between ministries is a problem... A
challenge in our social and health care system is that we have too many independent actors and organizations.
These actors have a tendency of thinking that they are unique. This tendency is visible in services: every actor and
organization wants to design services by themselves.' (Ministerial Adviser B, Ministry of Health and Social Care)

The interview of the local head of education revealed additional problems in the interaction between the state level and local level. She argued that the support from national level was insufficient and therefore the cities included in the nation-wide project were not able to create successfully new services. She considered that the issue is linked to the discontinuity of policies. In the present case, a particular challenge was a parliament election and the related change of the government in the middle of the experiment. The new government changed the focus of policies which affected on the continuation of the experiment - part of the resources allocated to it were transferred to other projects.

\footnotetext{
'At the same time, the government changed based on the new parliament, and the interest towards this experiment decreased. The experiment did not stop because it was planned to continue beyond the election, but the interest and resources were allocated to new efforts.' (Head of education and welfare services)
}

\subsubsection{The role of regulation and the issue of data confidentiality}

The interviewed ministerial advisers had identified a contradiction in the local desire for governmental advice. Local managers aim at relieving insecurities in the implementation of experiments by asking very strict instructions from the ministries. On the other hand, practitioners typically blame the existing instructions and feel that regulations diminish possibilities for collaboration between professionals. Common to both groups is the 'feeling of unclarity', which in social services is also justifiable due to diverse regulation; local managers and professionals have difficulties to know what is legal and what is not. Attitudes towards legislation vary, too - it is regarded as an enabler or as a barrier depending on the case. The ministerial actors themselves prefer a balanced view: they see instructions primarily as enabling, but do not favor non-regulated experimentation either. They believe that enabling directions enhance innovativeness and create opportunities for experimental development.

\footnotetext{
'The responsibility of the grass root professionals should be increased - now professionals require too precise instructions. Strict regulation does not solve things; we need more enabling regulation.' (Ministerial Adviser B, Ministry of Health and Social Care)

'The legislation in social care is not coherent...we have noticed it when we have started to develop digitalized services.' (Ministerial Adviser B, Ministry of Health and Social Care)
} 
The issue of regulation had caused debate in our experiment and was highlighted in the local level interviews. A specific aspect linked to regulation is data confidentiality. The professionals understood the need to protect citizens' privacy, but they argued that the current regulation hinders necessary information transfer between professionals and hampers the development of new integrative practices. The interviewed Data Protection Ombudsman and his colleague formulated the problem differently: the use of customer data is allowed if the customer gives permission to it and if the data is linked to the customer case at hand. However, the professionals may have difficulties in defining the relevant information, and this makes them uncertain about their needs for information. Uncertainty leads to the fear of mistakes and consequently to the avoidance of cooperation.

Data Protection Ombudsman noted that despite the sensitivity and the related challenges of the confidentiality issue, changes in the definition of confidential data are possible if they are made from the citizen-centric viewpoint and serve citizens' needs. The focus should be shifted from the service provider to citizens and to better and more holistic services to them. Customers' service needs should be considered central in any discussion between professionals. The role and power of IT systems is one problem that makes the situation difficult. Information management dominates the general management, resulting in a knowledge and leadership gap.

'Cooperation and information exchange among professionals are always possible if they are related to a specific customer need... However, irrelevant information, even if it concerns a specific customer, should not be passed to another professional.' (Lawyer from the Office of data Protection Ombudsman)

\footnotetext{
'The lack of knowledge about the data confidentiality leads to uncertainty. However, this uncertainty is not necessary. We should better describe customers rights: data should not be transparent and open to every professional, but its use should be linked to a specific case. The regulation related to the data confidentiality aims to protect customers against outsiders. However, the professional may experience it difficult to define who is an outsider.' (Data Protection Ombudsman)

\begin{abstract}
'There is no problem with information flow between professionals. I believe that the problem is the lack of expertise and management. The power of IT systems is difficult to overcome. Data protection does not prevent cooperation, but city managers can easily blame it. And if the managers do not know the situation, they cannot help the professionals, which should be their job.' (Data Protection Ombudsman)
\end{abstract}

\subsection{Lessons learned from the failed experiment}

Even though the common service plan was not implemented in the child and family services after some first trials, the interviewees agreed on its development potential. The following citations show that the central ideas of the experiment were considered valuable, and they were seen to provide a basis for the development of child and family service in the future:

'The only effective way to provide proactive child and family services is multi-professional collaboration and service integration... to support this development, we need integrated data systems instead of the fragmented systems that we currently use. In this experiment, we wanted to develop a comprehensive information reserve related to individuals' capacity to manage their lives. This is the direction in which the data systems will develop in the future.' (Strategy manager)

'We need to find the good things and notice the things that did not go well in the experiment. There were people who learned from the experiment and from the failures they faced. Now they know that in the future things should be introduced in a different way. That is the learning even though the experiment did not succeed as desired.' (Ministerial Adviser B, Ministry of Health and Social Care)

Thus, the interviewees underlined that the unsuccessful experiment was a valuable learning experience for the actors involved in the development work: it made the actors to understand the main pitfalls in the process. However, it was pointed out that the lessons learned need to be seriously and constructively analyzed in order to make them as assets in the future experimental activities. The 
experiences were also considered important for the service provision in the future social and health care centers, which are planned as part of an on-going renewal of social and health care in Finland. In the new care model, child and family services are planned in accordance with the key ideas of the experiment, as described by the manager responsible for customer processes:

'The service provision in the new social and health care centers is based on the same key ideas we had in our experiment. In the present social and health care renewal, all municipalities are forced to develop their child and family services according to the same model. They need to develop more integrated services. In our city, the experiment helps us to generate preparedness for the renewal.' (Manager responsible for customer processes)

\section{Concluding discussion}

Experimental approaches have been suggested as a successful innovation model in the current conditions of continuous and rapid changes. By integrating innovation and learning, and adaptive trial and error, they include a possibility to tackle the 'unknown' more efficiently than the approaches based on strong pre-planning. Experimental development has gained foothold in the public sector, too. Here it faces the specific challenges of administrative bureaucracy, top-down management and strong professional power. On the other hand, information technology creates new opportunities for overcoming professional silos and empowering citizens to participate in the production of services.

Our study examined a case project which aimed at developing a new integrated model of wellbeing in child and family services, based on multi-professional working. In the core of the new model was 'a common service plan' to which the user and the service providers commit themselves, and a digital platform which functions as their mutual information channel. The project met multiple challenges and was stopped before the planned dead line. However, it provided useful lessons for corresponding efforts in the future. In Table 2, we summarize the central findings that we have categorized on the basis of our theoretical frameworks: 1) the issues linked to the new kind of an innovation process (experimentation), and 2) the specific challenges of the public sector.

Table 2. Summary of the central findings of the study

\begin{tabular}{|l|l|l|}
\hline Theoretical perspective & \multicolumn{2}{|c|}{ Research results } \\
\hline Experiment-based innovation model & Application in the study case & Challenges in the application \\
\hline $\begin{array}{l}\text { Merging planning and } \\
\text { implementation }\end{array}$ & $\begin{array}{l}\text { The case was part of a nation-wide } \\
\text { exercise that explicitly aimed to promote } \\
\text { experimenting in the public context. }\end{array}$ & $\begin{array}{l}\text { The concept and nature of experimental } \\
\text { development were poorly known } \\
\text { among the participants. }\end{array}$ \\
\hline $\begin{array}{l}\text { Paying attention to learning } \\
\text { during the innovation process }\end{array}$ & An explicit focus on learning missed. & $\begin{array}{l}\text { Only the managers knew the aim of the } \\
\text { project. Deficient information among } \\
\text { the practitioners prevented learning. }\end{array}$ \\
\hline $\begin{array}{l}\text { Engaging users and grassroots } \\
\text { employees }\end{array}$ & $\begin{array}{l}\text { The basic idea of the integrated model of } \\
\text { wellbeing included the collaboration } \\
\text { between employees and service users. }\end{array}$ & $\begin{array}{l}\text { The participation of grassroots } \\
\text { employees was not organized, and the } \\
\text { recruitment of users was passive. }\end{array}$ \\
\hline $\begin{array}{l}\text { Framing and contextualizing the } \\
\text { problem at hand }\end{array}$ & $\begin{array}{l}\text { The target of the development (customer } \\
\text { processes in the integrated model) was } \\
\text { well specified by the managers. }\end{array}$ & $\begin{array}{l}\text { The applicability of experiment-based } \\
\text { development in the context of social } \\
\text { care was not discussed and turned out } \\
\text { to be too demanding. }\end{array}$ \\
\hline $\begin{array}{l}\text { Fostering adaptive trial and } \\
\text { error }\end{array}$ & $\begin{array}{l}\text { Trial and error -approach was not tested } \\
\text { because the actual implementation of the } \\
\text { new model was minimal. }\end{array}$ & $\begin{array}{l}\text { Trial and error could have been a risky } \\
\text { approach due to the sensitivity of the } \\
\text { problems of customers. }\end{array}$ \\
\hline
\end{tabular}

[Type here] 


\begin{tabular}{|c|c|c|}
\hline Mobilizing necessary resources & $\begin{array}{l}\text { The experiment was dependent on } \\
\text { governmental resources. Re-organization } \\
\text { of the work was not considered. }\end{array}$ & $\begin{array}{l}\text { The project was not prioritized among } \\
\text { the practitioners, fear of extra workload } \\
\text { weakened their motivation. }\end{array}$ \\
\hline \multicolumn{3}{|l|}{ Issues of the public sector } \\
\hline Traditional bureaucracy & $\begin{array}{l}\text { A top-down approach characterized the } \\
\text { project. }\end{array}$ & $\begin{array}{l}\text { The project was built on the enthusiasm } \\
\text { of a few managers; grassroots } \\
\text { professionals were engaged too late. }\end{array}$ \\
\hline Professionalism & $\begin{array}{l}\text { The case organization was on the way } \\
\text { towards hybrid forms of professionalism, } \\
\text { i.e. a combination of occupational and } \\
\text { organizational professionalism. }\end{array}$ & $\begin{array}{l}\text { Professionalism was not an issue in the } \\
\text { case. Multi-professional working was } \\
\text { familiar among the practitioners and } \\
\text { attitudes towards it were positive. }\end{array}$ \\
\hline Innovation management & $\begin{array}{l}\text { The top-down approach in the } \\
\text { experiment focused on the basic idea and } \\
\text { did not include systematic management } \\
\text { of the innovation process. }\end{array}$ & $\begin{array}{l}\text { The lack of management and leadership } \\
\text { made the experiment 'voluntary' and } \\
\text { secondary in the everyday work. }\end{array}$ \\
\hline Impacts of digitalization & $\begin{array}{l}\text { A digital platform for wellbeing data was } \\
\text { a central element in the experiment; it } \\
\text { was targeted to support the interaction } \\
\text { between professionals and service users. }\end{array}$ & $\begin{array}{l}\text { The need for a digital tool was not clear } \\
\text { to the practitioners. The solution was } \\
\text { 'cumbersome' and together with } \\
\text { confidentiality issues caused mistrust. }\end{array}$ \\
\hline $\begin{array}{l}\text { Interaction between local and } \\
\text { governmental levels }\end{array}$ & $\begin{array}{l}\text { Guidance from the responsible ministry } \\
\text { missed despite the nation-wide effort. } \\
\text { After the change of the government, } \\
\text { experimental development was no more } \\
\text { a focus in the political agenda. }\end{array}$ & $\begin{array}{l}\text { The practitioners were insecure about } \\
\text { the actual impacts of the project, } \\
\text { because they had experience on the } \\
\text { discontinuity of policy initiatives. This } \\
\text { weakened their motivation. }\end{array}$ \\
\hline Dissemination of innovations & $\begin{array}{l}\text { Dissemination was not considered in the } \\
\text { project plan at the local level and was not } \\
\text { discussed in the state-level project either. }\end{array}$ & $\begin{array}{l}\text { Organization of dissemination was } \\
\text { recognized as a problem by the } \\
\text { governmental representatives. }\end{array}$ \\
\hline
\end{tabular}

As regards the nature of the innovation process, our case was explicitly defined as a project of experimental innovation. It was part of a nation-wide effort whose aim was to promote experimental practices in the public sector. However, a systematic process that would merge planning and implementation, according to the principles of experimentation, was missing in the case. Our results revealed that the concept and nature of experimental development were poorly known among the participants, and only the managers were aware of the aim of the project. The central role of learning, which is regarded as the main benefit of experiments in the literature (e.g. Engvall et al., 2001), was not emphasized. There was a contradiction between the basic idea of the integrated model of wellbeing and its implementation: the model highlighted the engagement of employees and service users, but the participation of grassroots professionals was not organized, and consequently the recruitment of users was passive.

The approaches of bricolage (Fuglsang, 2010) and effectuation (Read et al., 2009) have suggested adaptive trial and error as the core approach in experimental innovation. They have also highlighted that an experiment is not the same as an unplanned process, but the problem at hand should be carefully framed and contextualized. In our case, the target of the project (customer processes in the integrated model) were well specified, but otherwise the requirements of an experiment seemed unfamiliar to the stakeholders. The applicability of experiment-based development in social care was not discussed, which was a severe shortcoming. Due to the sensitivity of the problems of customers, the use of the trial and error -approach in this context should have been analyzed in detail. Now, it turned out to be too challenging, but reasons behind this challenge remained unclear - lack of knowledge and poor organization of the project were intermingled with the real issues of customer situations. Another vulnerable point was the dependence of the experiment on governmental 
resources. This made the participants sceptical about the long-term continuity and resourcing of the new practices, which weakened their motivation.

Compared to the general challenges of innovation in the public sector, our case indicated that top-down practices are still strong. The interviewed managers were very eager about the renewal, but they did not acquire commitment from the grassroots level. On the other hand, occupational professionalism - which has been regarded as another typical barrier to the renewal of the public sector - was not an issue in our case. The participants had earlier experience of multi-professional work and they were positive towards the introduction of new ways of interacting. The local leaders and managers were not, however, capable of seizing this important opportunity. Our case is an illustrative example of the lack of skills in innovation management in the public sector. The focus in the development was on the idea phase; the implementation took place as a 'voluntary' process, which made it secondary in the everyday work.

Our case also brought up experiences about the development of digitalization. A central element in the experiment was a digital platform whose purpose was to support the interaction between professionals and service users. However, the tailor-made, price-driven solution was not userfriendly, and the need for a digital tool was not clear to the practitioners. The missing discussion on the specificities of the application area - social care - turned out to be a problem again. In addition to the intra-organizational discussion, a discussion would have been necessary between the local level and the regulatory, governmental level. Our interviews revealed that the views on the interpretation of the confidentiality issues and on the related possibilities of multi-professional information exchange clearly differed between local professionals and governmental actors.

The views between these two levels also differed concerning the whole exercise. Guidance from the responsible ministry missed despite the nation-wide effort, and the practitioners were doubtful about the impacts of the project, because they had experience on the discontinuity of policy initiatives. Actually, this discontinuity was realized in our case: after the change of the government, experimental development was no more a focus in the political agenda. A problem at both the local and national levels was the lack of the dissemination plan for the results. Thus, our study confirmed the earlier observation that the spread of public innovations is typically weak (Moulaert et al., 2005). Local actors do not have resources for broader collaboration and they do not see dissemination as their task. At the governmental level, common structures do not exist because of the administrative silos and collaboration models that would facilitate learning are rare. In order to promote experimental development, and public innovation more generally, these shortcomings should be tackled. Learning in and between projects, accelerating the dissemination of good practices, and common mechanisms and structures for them are required.

\section{References}

Alam, I. and Perry, C. (2002). A customer-oriented new service development process. Journal of Services Marketing, 16(6), 515-534.

Bovaird T. (2007). Beyond Engagement and Participation: User and Community Coproduction of Public Services. Public Administration Review, 67(5), 846-860.

Bryman, A., and Bell E. (2011). Business Research Methods, 3rd Ed. New York: Ox-ford University Press.

Buijs, J. (2003). Modelling Product Innovation Processes, from Linear Logic to Circular Chaos. Creativity and Innovation Management, 12(2), 76-93.

Chesbrough, H. (2011). Open Services Innovation: Rethinking Your Business to Grow and Compete in a New Era. New York: John Wiley \& Sons.

[Type here] 
Christensen, T. (2012). Post-NPM and changing public governance. Meiji Journal of Political Science and Economics, 1, 1-11.

Cooper, R.G., De Brentani, U. (1991). New industrial financial services: what distinguishes winners. Journal of Product Innovation Management, 8(2), 75-90.

Currie C., Lockett A., Finn R., Martin G. and Waring J. (2012). Institutional work to Maintain Professional Power: Recreating the Model of Medical Professionalism. Organization Studies, 33(7), 937-962.

Dent M. and Whitehead S. (2002). Introduction: Confguring the "new" professional. In Dent M. and Whitehead S. (eds.), Managing Professional Identities (pp. 1-19). New York: Routledge.

Eisenhardt, K. M. and Tabrizi, B. N. (1995). 'Accelerating Adaptive Processes: Product Innovation in the Global Computer Industry. Administrative Science Quarterly, 40(1), 84-110.

Engvall M., Magnusson P., Marshall C., Olin T. and Sandberg R. (2001). Creative approaches to Development: Exploring alternatives to Sequential Stage-gate Models (Working paper), Fenix WP 2001:17.

Evetts J. (2003). The sociological analysis of professionalism: Occupational change in the modern world. International Sociology, 18(2), 395-415.

Ferlie E., Fitzgerald L., Wood M. and Hawkins C. (2005). The nonspread of innovations: the mediating role of professionals. Academy of Management Journal, 48(1), 117-134.

Fuglsang, L. (2010). Bricolage and invisible innovation in public sector innovation. Journal of Innovation Economics, 5(1), 67-87.

Fuglsang, L. and Sørensen, F. (2011). The balance between bricolage and innovation: Management dilemmas in sustainable public innovation. Service Industries Journal, 31(4), 581-595.

Harrisson, D., Klein, J-L., Browne, P.L. (2010). Social innovation, social enterprise and services. In Gallouj, F. and Djellal, F. (eds.), The Handbook of Innovation and Services (pp. 197-281). Cheltenham and Northampton: Edward Elgar.

Hartley, J. (2005). Innovation in Governance and Public Services: Past and Present. Public Money and Management, 25(1), 27-34.

Hasu M. (2001). Critical Transition from Developers to Users - Activity Theoretical Studies of Interaction and Learning in the Innovation Process. Helsinki: University of Helsinki, Department of Education.

Honka A., Kaipainen K., Hietala H. and Saranummi N. (2011). Rethinking Health: ICT-Enabled Services to Empower People to Manage Their Health. IEEE Reviews in Biomedical Engineering, 4(2011), 119-139.

Hood C. (1991). A public management for all seasons? Public Administration, 69(1), 3-19.

Høyrup, S. (2012). Employee-Driven Innovation: A new phenomenon, concept and mode of innovation. In Høyrup, S., Bonnafous-Boucher, M., Hasse, C., Lotz, M. and Moller, K. (eds.). Employee-driven innovation: A new approach (pp. 3-33). New York: Palgrave Macmillan. 
Huberman, A.M. and Miles, M.B. (1994). Data Management and Analysis Method. In Denzin, N.K. and Lincoln, Y.S. (eds.), Handbook of Qualitative Research (pp. 428-444). Sage: Thousand Oaks.

Kesting, P. and Ulhøi, J.P. (2010). Employee-driven innovation: extending the licence to foster innovation. Management decision, 48, 65-84.

Koen, P., Ajamian, G., Burkart, R., Clamen, A., Davidson, J., D’Amore, R., Elkins, C., Herald, K., Incorvia, M., Johnson, A., Karol, R., Seibert, R., Slavejkov, A., Wagner, K. (2001). Providing clarity and a common language to the fuzzy front end. Research-Technology Management, 44(2), 46-55.

Langergaard, L.L. (2011). Understanding of 'users' and 'innovation' in a public sector context. In Sundbo. J. and Toivonen, M. (eds.). User-based Innovation in Services (pp. 203-226). Cheltenham and Northampton: Edwards Elgar.

Lundvall, B-A (2001). Innovation Policy in the Globalizing Learning Economy. In Archibugi, D., Lundvall, B-Å. (eds.). The Globalizing Learning Economy (pp. 273-291). Oxford: Oxford University Press.

Moore M. and Hartley J. (2008). Innovations in Governance. Public Management Review, 10(1), 320.

Moorman C. and Miner A.S. (1998). The convergence of Planning and Execution: Improvisation in New Product Development. Journal of Marketing, 62(3), 1-20.

Moulaert F.F., Martinelli, F., Swyngedouw, E., Gonzalez, S. (2005). Towards Alternative model(s) of Local Innovation. Urban Studies, 42(11), 1969-1990.

Mäkinen M. (2006). Digital Empowerment as a Process for Enhancing Citizens' Participation. ELearning, 3(3), 381-395.

Määttä, H., Ruutu, S., and Toivonen, M. (2014). Revealing the Complexities of Health Care Renewal: A System Dynamics Approach. In Proceedings of the 5th International Conference on Applied Human Factors and Ergonomics AHFE 2014 (4th ed.)

Newman, J. and Clarke (2009). Public, Politics and Power: Remaking the Public in Public Services. Thousand Oaks and London: Sage.

Nordlund, H. (2009). Constructing Customer Understanding in Front End of Innovation, Tampere: Acta Universitatis Tamperensis.

Orr, L.L. (1999). Social experiments: Evaluating public programs with experimental methods. Thousand Oaks, California: Sage Publications, Inc.

Papastergiou, M. (2009). Exploring the potential of computer and video games for health and physical education: A literature review. Computers Education, 53 (3), 603-622.

Read, S., Dew, N., Sarasvathy, S.D., Song, M., Wiltbank, R. (2009). Marketing Under Uncertainty: The Logic of an Effectual Approach. Journal of Marketing, 73(5), 1-18.

Rhodes, R.A.W. (1996). The New Governance: Governing without Government. Political Studies, XLIV, 652-667. 
Samoocha D., Bruinvels D. J., Elbers N. A., Anema J. R. and van der Beek A. J. (2010). Efectiveness of web- based interventions on patient empowerment: A systematic review and meta-analysis. Journal of Medical Internet Research, 12(2), e23.

Sarasvathy, S.D. and Kotha, S. (2001). Dealing with Knightian Uncertainty in the New Economy: The Real Networks Case'. In Butler, J. (ed.), Research on Management and Entrepreneurship (pp. 31-62). Vol. 1, Greenwich, CT: IAP Inc.

Sarasvathy, S.D. (2008). Effectuation: Elements of entrepreneurial expertise. Cheltenham and Northampton: Edward Elgar.

Skelcher C. and Smith S.R. (2015). Theorizing hybridity: Institutional logics, complex organizations, and actor identities: The case of nonprofts. Public Administration 93(2), 433-448.

Sundbo, J. (2008). Customer-based innovation of knowledge e-services - the importance of afterinnovation. International Journal of Services Technology and Management, 9(3-4), 218-233.

Sundbo, J., Toivonen, M. (2011). Introduction. In Sundbo J., Toivonen M. (eds.), User-based innovation in services. Cheltenham and Northampton: Edward Elgar.

Sørensen, E. (2002). Democratic Theory and Network Governance. Administrative Theory and Praxis, 24(4), 693-720.

Tempo Economics (2017). Kuntakokeilut kuntien velvoitteiden vähentämisen tueksi -hankkeen arviointi. Retrieved from https://vm.fi/documents/10623/1230344/Tempon+loppuraportti/7e97f66a8be7-4680-9b3b-be530d3667fa/Tempon+loppuraportti.pdf

Tummers, L., Bekkers, V., and Steijn, B. (2009). Policy alienation of public professionals: Application in a New Public Management context. Public Management Review, 11(85), 685-706.

Torfing, J., Triantafillou, P. (2013). What's in name? Grasping new Public Governance as a politicaladministrative system. International Review of Public Administration, 18 (2), 9-25.

Toivonen, M. (2010). Different types of innovation processes in services and their organisational implications. In Gallouj, F. and Djellal, F. (eds.): The Handbook of Innovation and Services (pp. 221249). Cheltenham and Northampton: Edward Elgar.

von Hippel, E. (1978). Successful industrial products from customer ideas. Journal of Marketing, 42(1), 39-49.

von Hippel, E. (1986). Lead users: A source of novel product concepts. Management Science, 32(7), 791-805.

Webb, T. L., Joseph, J., Yardley, L., and Michie, S. (2010). Using the internet to promote health behavior change: A systematic review and meta-analysis of the impact of theoretical basis, use of behavior change techniques, and mode of delivery on efcacy. Journal of Medical Internet Research, 12(1), e4.

WHO (1997). The Jakarta Declaration on Health Promotion in the 21st Century, HPR/HEP/4ICHP/BR/97.4. WHO, Geneva.

Windrum, P. (2008). Introduction. In Windrum, P., Koch, P. (eds.), Innovation in Public Sector Services: Entrepreneurship, Creativity and Management (pp. 3-20.). Cheltenham and Northampton: Edward Elgar.

[Type here] 